were analysed by paperelectrophoresis. Total blood cholesterol levels, blood sugar levels and total protein values were measured also. Compared with normal values (12 cases), the results were as follows.

1) Serum protein fractions showed a marked decrease in albumin and an increase in $\alpha_{2}$-globulin and $\gamma$-globulin. The degree of increase in $\alpha_{2}$-globulin became more and more significant as the generations progressed. The lipoprotein index increased in each generation. Glycoprotein fractions showed changes analogous to those of the protein fractions.

2) Total cholesterol levels were slightly increased in $F_{4}$ and $F_{5}$. Blood sugar levels were markedly increased in every generation. Total serum protein values were normal.

3) It is concluded that the serum protein, lipoprotein and glycoprotein patterns in these rabbits showed changes before alloxan administration, and presented moreover changes seen in alloxan diabetic rabbits.

4) These alterations are similar to those in a few cases of human diabetes.

\title{
Insulin Sensibility in the Pregnancy
}

By

\section{Takashi YAMADA, Kakuichi NISHIGORI and Kazuya YANO}

From the Department of Obstetrics and Gynecology, Kyoto University, School of Medicine

This work, the insulin sensibility of the pregnant, has been performed as a part of the co-operative investigation in our department concerning the carbohydrate metabolism in the pregnant woman.

In accordance with the modified Radoslav's method the blood was taken every 10 minutes after a single injection of 5 units of insulin intravenously eary in the morning on an empty stomach.

The blood sugar was estimated by the Somogyi's Anthron method. The insulin sensibility coefficient of the pregnant was proved to be lowered, as compared with the non-pregnant, moreover declining much more as the month of pregnancy proceeds. Regarding to the rate of covery it was almost the same in both groups.

Next, the I/G ratio in the modified Himsworth's method, namely the indicator of insulin sensibility, was proved to decline month after month in pregnacy.

The inorganic phosphate in blood was estimated by the Nakamura's method after the intravenous administration of insulin according to the modified Radoslav's method. The decreasing rate of the inorganic phosphate in blood caused by the insulin administration was proved to get lowered in the pregnant comparing with that of the non-pregnant. This may indicate that the vicissitudes of the inorganic phosphate in blood run almost pararell with that of blood sugar.

In conclusion, the results obtained above may suggest that the insulin tolerance must increase in the pregnant, and it could be inferred, as the interpretation of this cause that the fluctuations of the functions of the pituitary-adrenocortical system would have something to do with it. 


\section{妊娠時における Insulin 感性}

京都大学医学部産婦人科学教室

山田 隆治, 西郡 確一, 矢野一哉

内 容目次

緒 言

第 1 筸 奏駼方法

第 2 章 垁験成旗
第 3 章 総括並びに考按

結 論

緒言

弤娠個体には糖質代謝に変諷のあることは従来より周知の所であり，糖質代謝を規正する内分泌㵴器機能 の相互間の平衡状態にも何等かの変調が存在するのではないかというととは容易に考光られる.

一般に脳下垂体ホルモン，殊に生長ホルモンと ACTH 及び副婜皮質ホルモンは愺臟より産生される Insulin 亿拮抗して糖質及びアミノ酸代謝に種々の影響を与えることはよく知られており1223)，てれ等の木 ルモンは抗インシュリン・ホルモンとして一定の平衡を保つことにより個体の糖質代謝は規定されていると いわれている，従つて体外より少量のインシュリンを与えることは，乙れらの Hormone 間の平衡状態に 何らかの変化を与え，内分泌環境にある乱れが生ずるととあ当然考えられる．従来とも Insulin 感性試験 は，組織の糖質利用を促進する Insulin 作用の強弱を血糖降下の状海より測定せんとして実施されてきた のであるが，現在では糖質代謝の様相またはこれを規正するホルモン平衡を窥う目的で一般に広く行われて いる.

よつて私達は「妊娠個体の糖質代謝に関する研究」の一環として，その糖質代謝位相を規定するホルモン 平衡の場功この一端を検討す心゙く, Insulin 感性試験を行い, てれについて考察を加えることにした。

\section{第 1 章 実 験 方 法}

実験材料はすべて本院に通院或いは入院した正常妊婦であり，妊娠初期（弤娠 $2 \sim 3$ 力月）中期（弤娠 5 〜 カ月) 末期（妪娠 9 〜 10 月）及び分婏予定日超過の 4 群に分けて検討した. 刘照としては本学の助産 婦学校学生（年令21〜25才）を用いた。

Insulin 感性試験は Radoslav 法及び Himsworth 法の葛谷氏等の変法苂に準じて行つた.

\section{1) Radoslav 変法}

早朝空腹時に安静位をとらせ，血糖值を20分毎に 2 ～回測定し，その平均值を試験前值とし，Insulin （Fiselin） 5 单位を単独静注負荷し，10分毎に60分までと，以後 90 分，120分之 8 回，駆血するととなく时静 脈より採取，それぞれ $0.1 \mathrm{cc}$ そつき血糖值を Somogyi の Anthron 法 ${ }^{506)}$ とり測定し，試験前值と Insulin 負荷による最低值との差を，最低值に達する時間（分）で割つたものをInsulin 感性指数として計算した。

\section{2) Himsworth 変法}

前法同様に早期空腹時に試験前值を求め，50\%ブドウ糖液 $40 \mathrm{cc}$ を静注負荷し，注射後 3 分，以後 10 分每に 60 分まで 6 回採血し，血糖值を測定した．次いで 1 ～日の間隔をおいて $50 \%$ ブドウ糖 $40 \mathrm{cc}$ 亿 Insulin 5 単 位を混じたものを静注し，前回と同様に血糖值を測定し，而者の血糖曲線から Insulin 感性を求めた。

即ち陚験前值及び 注射後 3 分值を 0 分值とし，試験前値において 水平線を引き血糖基準線とし，負荷後 40分の点において，乙れに対し重正線を引き特間基集線として $\mathrm{I} / \mathrm{G}$ 比を求めた， $\mathrm{G}$ 上はブドウ糖単独静注時

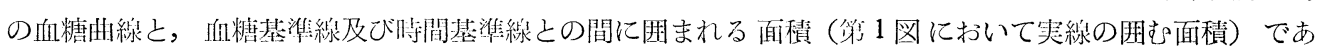


る. I とは Insulin ブドウ糖同時負荷の場合得 られた同上の面積（第1図において点線の囲吉面 積）をGより減じた面積である. Insulin を負荷し た場合は40分時で既に血糖基準線より低下すること があるが，乙の時は基準線より上の面積值を正，下 のそれを負として計算する。

\section{3) Insulin 負荷時の血中無機燐測定}

前述の Rodoslav 变法実施に際して，同時に血中 然機橉の消長を観るた妨，血漿を10\% T.C.A. で 除蛋白して中村氏法》りより，その無機燐を測定し た.

\section{- 第 2 章 実 験 成 績}

\section{1) Radoslav 変法による Insulin 感性試験}

第 1 表に示す如く Insulin 感性指数は正常非妊 群では，平均2.92（3.41２.68）であつたのに対し て弤娠初期群は平均 $2.13(3.00 \sim 1.69)$, 妊娠中期

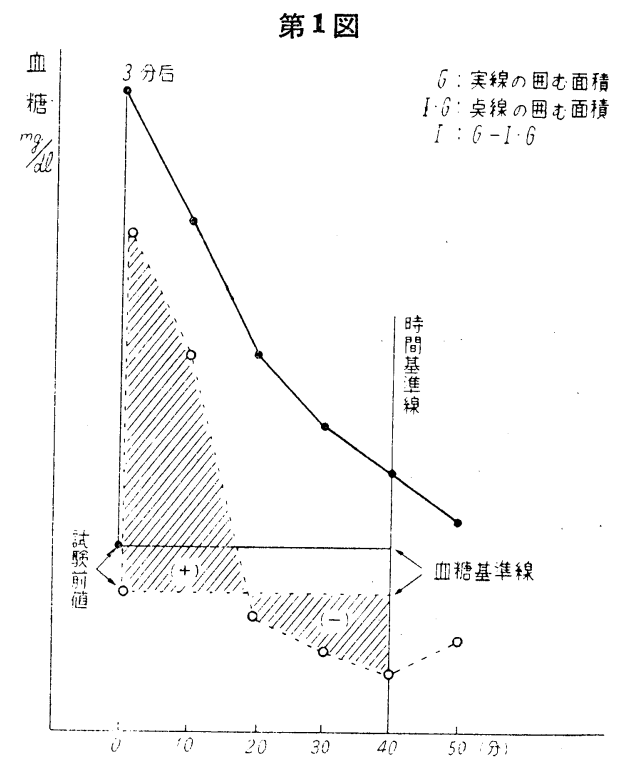
群は平均1.75 (1.96〜1.52)，妊娠未期群は平均1.62 (2.01 1.01) であつて，明らかに妊娠群では逐月的に Insulin 感性指数は小さくなつている.

血糖の最低值に達するまでの時間は，弤娠初期及び中期群に各々 1 例のみ30分のものがあつたが他の全部 が 20分でありその差はないといつてよい，血糖下降の䋓対量は正常非妵の平均 58.3 (68.1 43.6) に対し

第1表 インシュリン感性（Radoslav 法）

\begin{tabular}{|c|c|c|c|c|c|c|c|c|}
\hline & & $\begin{array}{l}\text { 武験前值 } \\
\left(\begin{array}{cc}\text { 空腹時 } \\
\text { 血 }\end{array} \text { 糖 }\right.\end{array}$ & 最低值 & $\begin{array}{l}\text { 血糖下降 } \\
\text { の絶対量 }\end{array}$ & $\begin{array}{c}\text { 最低值に } \\
\text { 達す方ま } \\
\text { での時間 } \\
\text { (分) }\end{array}$ & $\begin{array}{l}\text { インシュ } \\
\text { リン感性 } \\
\text { 指数 }\end{array}$ & $\begin{array}{c}\text { 恢復時間 } \\
\text { (分) }\end{array}$ & 恢復度 \\
\hline \multirow{6}{*}{$\begin{array}{l}\text { 正 } \\
\text { 常 } \\
\text { 非 } \\
\text { 娃 }\end{array}$} & \multirow{6}{*}{$\begin{array}{l}\text { 対 } \\
\text { 照 }\end{array}$} & 103.2 & 35.1 & 68.1 & 20 & 3.41 & 40 & 1.34 \\
\hline & & 98.4 & 38.8 & 59.6 & 20 & 2.98 & 70 & 0.71 \\
\hline & & 102.4 & 35.6 & 66.8 & 20 & 3.34 & 40 & 1.32 \\
\hline & & 89.7 & 46.1 & 43.6 & 20 & 2.18 & 40 & 0.76 \\
\hline & & 98.5 & 45.0 & 53.5 & 20 & 2.68 & 70 & 0.57 \\
\hline & & & & & & $\begin{array}{l}\text { 平均 } \\
2.92\end{array}$ & & \\
\hline \multirow{5}{*}{$\begin{array}{l}\text { 弤 } \\
\text { 娠 } \\
\text { 初 } \\
\text { 期 }\end{array}$} & 3ヶ月 & 88.4 & 48.5 & 39.9 & 20 & 2.00 & 40 & 0.89 \\
\hline & 3 ケ月 & 101.3 & 41.2 & 60.1 & 20 & 3.00 & 40 & 1.15 \\
\hline & 2ヶ月 & 99.6 & 45.0 & 54.6 & 30 & 1.82 & 60 & 0.67 \\
\hline & 2ヶ月 & 95.5 & 57.7 & 37.8 & 20 & 1.69 & 40 & 0.88 \\
\hline & & & & & & $\begin{array}{l}\text { 平均 } \\
2.13\end{array}$ & & \\
\hline \multirow{5}{*}{$\begin{array}{l}\text { 妊 } \\
\text { 脤 } \\
\text { 中 } \\
\text { 期 }\end{array}$} & 5ヶ月 & 100.5 & 55.0 & 45.5 & 30 & 1.52 & 30 & 1.03 \\
\hline & 6ヶ月 & 90.5 & 55.5 & 35.0 & 20 & 1.75 & 30 & 0.78 \\
\hline & 6ケ月 & 88.1 & 49.0 & 39.0 & 20 & 1.96 & 40 & 0.84 \\
\hline & 7ケ月 & 92.6 & 57.2 & 35.4 & 20 & 1.77 & 40 & 0.86 \\
\hline & & & & & & $\begin{array}{l}\text { 平均 } \\
1.75\end{array}$ & & \\
\hline
\end{tabular}

第35巻 第10晃 


\begin{tabular}{c|c|c|c|c|c|c|c|c}
\hline & 10ケ月 & 88.3 & 56.1 & 32.2 & 20 & 1.61 & 30 & 0.63 \\
妊 & 10ケ月 & 90.1 & 58.7 & 31.4 & 20 & 1.57 & 20 & 0.90 \\
娠 & 10ケ月 & 86.7 & 46.5 & 40.2 & 20 & 2.01 & 30 & 0.98 \\
末 & 81.5 & 48.3 & 33.2 & 20 & 1.66 & 20 & 1.02 \\
期 & 9ケ月 & 81.8 & 45.1 & 36.7 & 20 & 1.84 & 20 & 1.08 \\
& & 86.5 & 56.2 & 30.3 & 20 & 1.01 & 30 & 0.70 \\
& & & & & 平均 & & \\
\hline
\end{tabular}

て娃娠初期は平均 53.1 (60.1 37.8), 妊娠中期は平均38.7(45. 5 35.0), 妊娠末期 は平均 34.0 (40.2 30.3) であつて，妊婦で はその下降の絶対量は非妊婦に比 して少なく，しかも妊娠の場合は 逐月的にその量は少なくなつてお り,てのために上述の如き Insulin 感性指数に大なる差を生ずるので ある，との際，最低值に達した血 糖值が，試験前值より $15 \mathrm{mg} / \mathrm{dl}$ 低 い值にまで上昇する平均速度(〔試 験前值 $-15 \mathrm{mg} / \mathrm{dl}]$ - 最低值/恢復時間）を求めて 恢復度としたが，その值は各群の間に大差は認め られない。

次に分婏予定日超過例について見るに第 2 表に 示す如く，血糖下降の絶対量は平均32.9（47.6～

第3表 インシュリン感性（Himsworth 法）

\begin{tabular}{|c|c|c|c|c|c|}
\hline & & $\mathrm{G}$ & $\mathrm{I} \cdot \mathrm{G}$ & I & $\mathrm{I} / \mathrm{G}$ \\
\hline \multirow{5}{*}{$\begin{array}{l}\text { 正 } \\
\text { 常 } \\
\text { 韭 } \\
\text { 弤 }\end{array}$} & \multirow{3}{*}{ 対 } & 373.8 & 161.9 & 211.9 & 0.56 \\
\hline & & 518.5 & 118.9 & 399.6 & 0.77 \\
\hline & & 430.9 & 132.8 & 298.1 & 0.69 \\
\hline & 照 & 413.4 & 24.8 & 388.6 & 0.94 \\
\hline & & 420.9 & 95.6 & 325.3 & 0.77 \\
\hline \multirow{3}{*}{$\begin{array}{l}\text { 弤 } \\
\text { 娠 } \\
\text { 初 } \\
\text { 期 }\end{array}$} & III & 281.5 & 131.4 & 150.1 & 0.53 \\
\hline & II & 375.1 & 183.1 & 192.0 & 0.51 \\
\hline & 娄 & 410.5 & 182.3 & 238.2 & 0.58 \\
\hline \multirow{3}{*}{$\begin{array}{l}\text { 妊 } \\
\text { 娠 } \\
\text { 中 } \\
\text { 期 }\end{array}$} & $v$ & 428.3 & 294.0 & 134.3 & 0.31 \\
\hline & VI & 357.0 & 195.1 & 161.8 & 0.45 \\
\hline & $\mathrm{V}$ & 325.2 & 183.0 & 142.2 & 0.44 \\
\hline \multirow{3}{*}{$\begin{array}{l}\text { 姓 } \\
\text { 娠 } \\
\text { 期 }\end{array}$} & $X$ & 301.1 & 232.3 & 68.8 & 0.23 \\
\hline & IX & 293.2 & 166.7 & 126.5 & 0.43 \\
\hline & $X$ & 436.8 & 304.6 & 132.2 & 0.30 \\
\hline
\end{tabular}

第 2 表 予定日超過例

\begin{tabular}{|c|c|c|c|c|c|c|c|}
\hline No. & 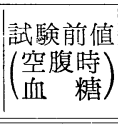 & 最低值 & $\begin{array}{l}\text { 血糖下降 } \\
\text { の絶対量 }\end{array}$ & $\begin{array}{c}\text { 最低值に } \\
\text { 達す圪 } \\
\text { の時間 } \\
\text { (分) }\end{array}$ & $\mid \begin{array}{l}\text { インシュ } \\
\text { リン感性 } \\
\text { 指数 }\end{array}$ & 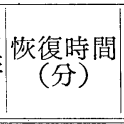 & 恢復度 \\
\hline 1 & 85.3 & 57.3 & 28.0 & 30 & 0.93 & 20 & 0.90 \\
\hline 2 & 83.6 & 51.0 & 32.6 & 40 & 0.82 & 20 & 1.24 \\
\hline 3 & 86.1 & 53.5 & 32.6 & 30 & 1.09 & 60 & 0.50 \\
\hline 4 & 93.5 & 59.5 & 34.0 & 30 & 1.13 & 30 & 0.68 \\
\hline 5 & 82.4 & 59.6 & 22.8 & 30 & 0.76 & 30 & 0.42 \\
\hline 6 & 99.8 & 52.2 & 47.6 & 50 & $\begin{array}{c}0.95 \\
\text { 平均 } \\
0.95\end{array}$ & 40 & 1.26 \\
\hline
\end{tabular}

第 2 図

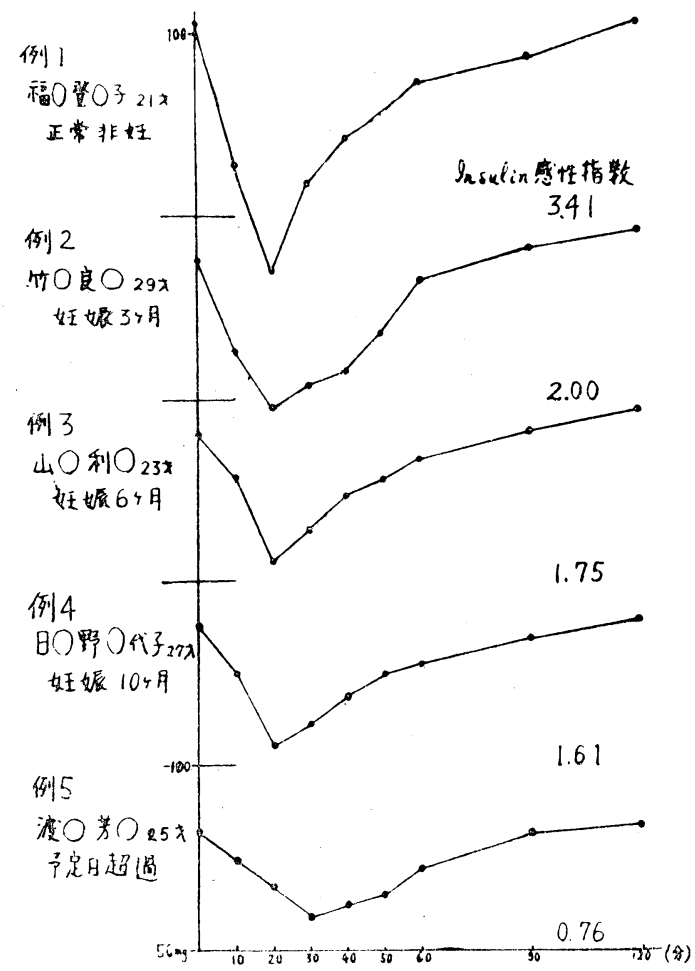


22.8) で前述の各群より小さく，更に最低值に達するまでの時間も30分以下のものが1例もない，従つて Insulin 感性指数も0.95（1.13〜0.76）と更に小さい. しかし恢復度には大差は認められなかつた.

各群における代表例を血糖曲線で図示すると第 2 図の如くである。即ち妊娠群では反応曲線の勾配が逐月 的にゆるやかになつていることが示され Insulin 感性の低下が明らかに認められる。

第3 図 1

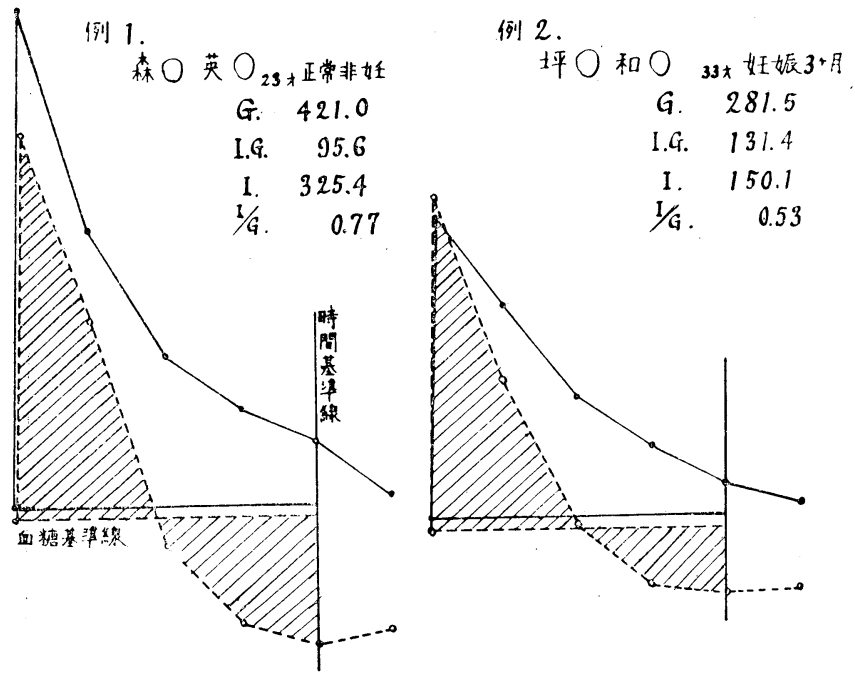

第 3 図 2

例 3 .

谷○里 ${ }_{32 \pi}$ 奸脈 6 月

例 4 .

G. 428.3

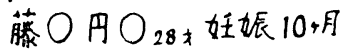

1.6. 294.0
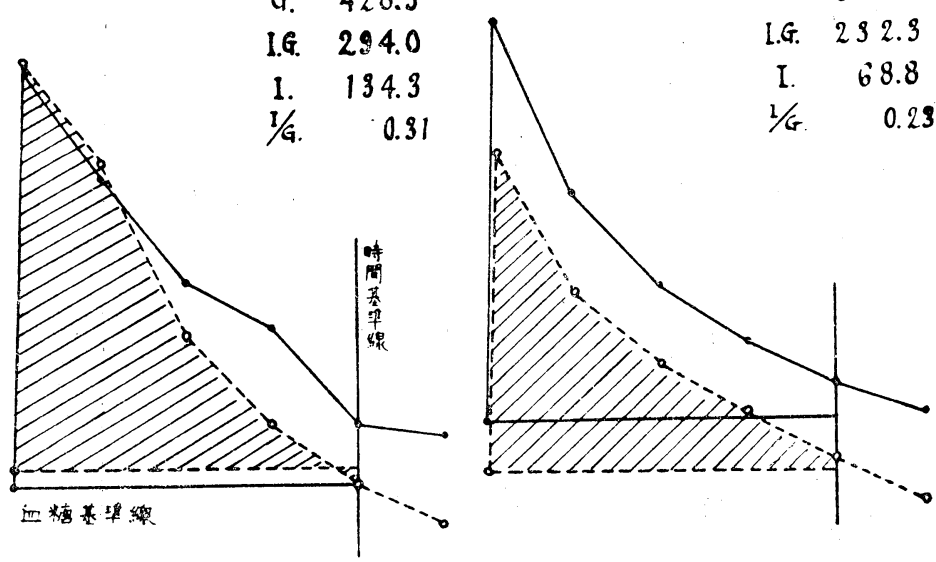

註) 実験 - $50 \%$ ブドウ糖 $40 \mathrm{cc}$ 静注後の血糖曲線

点線 $\bigcirc \cdots \cdots .50 \%$ ブドゥ糖 $40 \mathrm{cc}+$ Insulin 5 単位静注後の血糖曲線.

実線の团む面積 $\mathrm{G}$ ，点線の囲む面積 I.G と方る

$$
\mathrm{I} / \mathrm{G}=\frac{\mathrm{G}-\mathrm{I} \cdot \mathrm{G}}{\mathrm{G}}
$$




\section{2) Himsworth 変法による Insulin 感性試験}

この成績は第 3 表に示す如くである. 即ちI/Gは正常非嫕では平均 $0.75(0.94 〜 0.96)$ であるのに対し $\tau$ ，妊娠初期は平均 $0.54(0.58 \sim 0.51)$ ，妊娠中期は平均 $0.40(0.45 \sim 0.31)$ ，弤娠末期は平均 $0.32(0.43 \sim$ 0.23) であり，明らかに妊娠群では逐月的にI/Gが小さくなつている.

各群の代表例を図示すると第 3 図の如くなる。

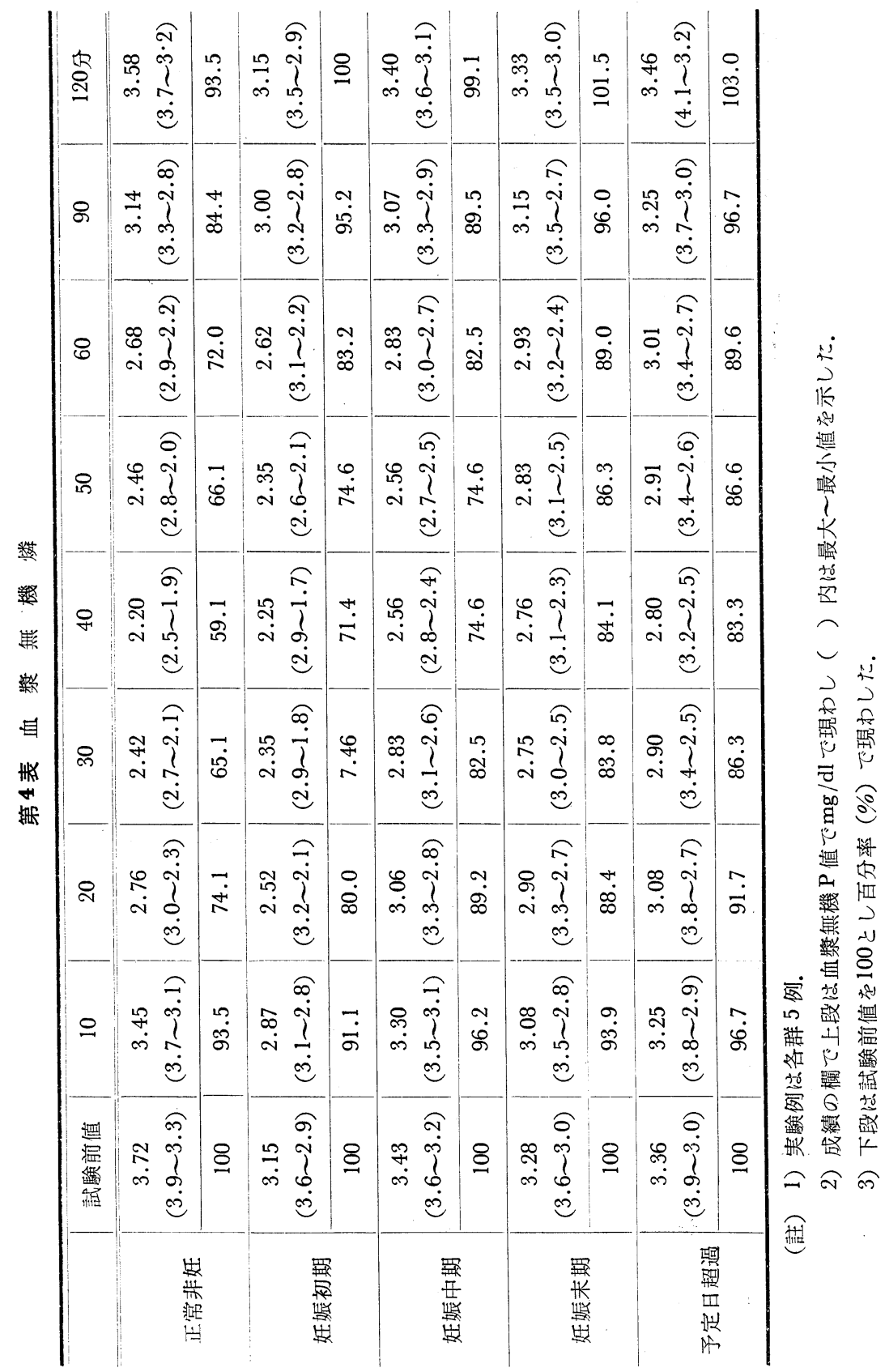




\section{3) Insulin 負荷時における血漿無機燐の動向}

その成績は第 4 表に示す如くである.

試験前值を100とすると，最低值は正常非妊では平均59.1（64.1～52.8）にまで下降しているのに対して， 妊娠初期は平均71.4 (80.6〜 58.6), 妊娠中期は平均74.6 (80.0〜69.4), 姲娠末期は平均83.3 (88.9〜 75.8) であり，明らかに奸娠時には正常非弤に比へて Insulin 負荷による血漿無機燐の減少度は小であり，且つ逐 月的にその傾向は大となつている．．その動向を曲線で示すと第 4 図の如くである． 即ち Radoslav 変法を用 いて検索した血糖曲線之略々平行しており (第 3 図参照)，妊娠時には逐月的には勾配がゆるやかとなつて いる. しかし無機燐が最低值になる時間は，血糖のそれよりあ10〜20分遅れている.

\section{第3 章 総括並ひに考按}

以上の実験成績を要約すると，妊娠時には Insulin 感性は逐月的に低下し，血糖曲線はそれ に応じて勾配がゆるやかになるのと歩調を合わせ て Insulin 負荷時の血嶈無機燐減少度屯 同様の 消長を示した。

従来加ら Insulin 感性の測定は, 組織の糖質利 用を促進する Insulin 作用の強弱を測定するて とを目的として，広く種々の方法で行われて来た が，近来特に内分泌学の進歩に伴い，Insulin と これに拮抗する種々のホルモンとの平衡状態を窅 い知るととを目標に用いられるに至り，従来から の Insulin 感性試験には種々の改良が行われ， また表示法にも様々の検討が加えられて来たとと は周知のところである。

私達は Insulin 感性を現わすのに，葛谷氏等 の提唱した Radoslav 法の変法による血糖下降度 (Insulin 感性指数) を用いた，更に方の成績を 検討する目的で Himsworth 変法によるI/G t求记 たのである。即ち本実験の Radoslar 変法の成績 で示されているように，試験前值は妊娠各群が 何れあわずかではあるが，平均して低い值を示し ている. 木法は試験前值が比較的近似している場 合にのふ検討し得るあのであるとされている8 ので，果して木実験成績が比較検討し得るあのかどうかに疑 念があるので更に Himsworth 変法により検索してみたのである．木法はブドウ糖と Insulin を同時に与え る場合，その Insulin がブドウ糖投与による過血糖を抑制する程度は Insulin 感性によつて決定されると いう考兊に基ずいており9，ブドウ糖投与によつて高くなつた過血糖をInsulin によつてどの程度低下せし ぬ得るかを判定するので, 試験前值のある程度の差は当然無視し得るとされている9. 私達の実験では Himsworth 変法で検討した結果は, Radoslav 変法の結果と一致した成績它得ることが出来た. 即ち妊娠時には逐 月的に Insulin 感性指数が小さくなることは，I/G 值においても全く同様の傾向を示した.

一般に血漿無機燐は末梢におけるブドウ糖の利用度の指標とされている。 また正常個体に Insulin を投与 する之，血漿無機燐は正常以下に減少することが知られている．本実験においても Insulin 投与により血漿 無機燐は減少し，血糖が最低值となる時間より10２0分遅れて無機燐も最低值を示し，略々血糖曲線之同様 の消長を示した。をしててれが姄娠時では逐月的に燐の減少度は少なくなり。をの反応曲線の勾配む濑次ゆ 
るやかになるととが明らかに認められた。

従来から Insulin とこれに拮抗する種々の抗 Insulin-Hormone の平衡状態において個体の糖質代謝は規 正されているという見解が一般に表明されているが，特に脳下垂体ホルモン就中成長ホルモン及び ACTH 並び副腎皮質ホルモンは Insulin 亿拮抗していることは周知のとてろである. 即ち Insulin 投与は血中好

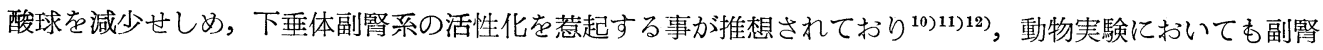
皮質分泌昂進の起るととが副腎皮質アスコルビン酸 ${ }^{13)}$, リポイドの減少 ${ }^{12}$, 血中及び尿中ステロイドの增加 ${ }^{15}$ ) 等によつて報告されている．乙のととは一般に Insulin の低血糖作用が Stress となつて下垂体副腎皮質系 の機能昂進を来たさしめるとなす見解をとるものが多いようであり，従つて Insulin 投与による代謝の変化 の相違を観察することによつて下垂体副腎系の機能の一端を覛う一手段とされている ${ }^{16)}$. R.C. de Bodo 等 ${ }^{17}$ ) の成績に見られるように，下垂体剔除白鼠の Insulin 投与による血糖下降度が，成長ホルモンの注射により 著明に減少すること，また H.L. Mason 等 ${ }^{18}$ )の成績で ACTH 投与により Insulin 負荷時の血糖下降度が小 さくなることが明確に示されている。最近において R.L. Burt ${ }^{19)}$ は Insulin 負荷時の血糖曲線と血漿無機燐 の消長より妊娠36週以後では Insulin 亿対する感受性が低下することを推想している。

以上のととから本実験において示された弤娠時において Insulin 感性が逐月的に低下することは，妊娠時 には濑次 Insulin 耐性が堌强すると理解され，乙れには下垂体副腎皮質系が関与しているあのであることを 示晙しているといえよう.

\section{結 論}

正常非妊婦を刘照に妊婦を初期，中期，末期，分婏予定日超過の 4 群に分引 Radoslav 変法に準じて Insulin 感性試験を行い，更に Himsworth 变法により乙れを検討し，また Radoslav 変法実施に際して併せて 血漿無機燐の動向を検索した結果，妊娠時には Insulin 感性が逐月的に低下し，乙れを血糖曲線からみれば Insulin 負荷による反応曲線の勾配は遂月的にゆるやかになつてゆくが，乙れと歩調を合わせて血漿無機燐 も同様の反応曲線を描き，その減少度が軽度となつている。

以上の実験結果から娃娠時には逐月的に Insulin 耐性が増強するが，乙れには下垂体副腎皮質系の変調が 関与しているものと推想する。

本論文の要旨は第32回日本内分必学会総会で発表した.

稿を終るに臨み終始御愁篤なる御指導御校閲を賜つた恩師三林教授, 大橋助教授並びに西村講師に対し深 甚なる謝意を捧げる。

な扔本実験は文部省科学研究費によるととろ大であつた。

\section{主 要 文 献}

1) Lotspeich, W.D. : J.B.C., $185: 221$ (1950)

2) Renold, A.E. : J.B.C., $204: 533$ (1953)

Reid, E. : J. Endocrinol., 9 : 210 (1953)

4) 葛谷等 : 内分泌のつぞい，第 2 集，324 (1952)

藤井 : 生化実実験 (定量篇) 154 芸化学誌, $24: 197$ (1950)

6) 茂手木 : 日新医学, $37: 95$ (1950)

7) 中村 : 日本農

H.P. : Lancet, 1936 I : 127

8) Himsworth, H.P. : J. Physiol., $81: 29$ (1934)

9) Himsworth,

11) Perlmutter, M. 等 : J. Clin. Endocrinol., $11: 277$. (1951)

12) Tsai, S.Y. : Proc. Soc. Exp.

Biol. Med., 69 : 782 (1950)

13) Dury, A. : Am. J. Physiol., $163: 56$ (1950)

14) Long,

C.N.H. 等 : J. Clin. Endocrinol., $8: 587$ (1948)

16) 林：日本内分泌学会誌，31:503 (1955)

15) Paschkis, K.E. 等 : Endocrinol., 47 : 338 (1950)

(1950)

18) Mason, H.L 等 : J. Clin. Endocrinol., $8: 1$ (1948)

17 de Bodo, R.C. 等: Am. J. Physiol., $163: 310$ and Gynecol., $7: 658$ (1956)

19) Burt, R.L. : Obstetrics 